\title{
Report on hearing loss in oncology
}

\section{Christiane Schultz ", Maria Valéria Schmidt Goffi- Gomez ${ }^{2}$, Patrícia Helena Pecora Liberman ${ }^{3}$, André Lopes Carvalbo}

Keywords: cisplatin/adverse effects, oncology, hearing loss/ classification, chemotherapy/adverse effects.

\section{Summary}

\begin{abstract}
C
isplatin is used frequently as an antineoplastic drug in the treatment of many different cancers. However, when used in doses over $360 \mathrm{mg} / \mathrm{m}^{2}$, ototoxicity may ensue, resulting in loss of hearing. Criteria for identifying and quantifying hearing loss have been devised. Aim: To describe the features of different hearing loss classification systems and to identify their implications and use in oncologic patients. Method: Hearing loss was classified in 31 patients before and after chemotherapy, according to different criteria, assessing the sensitivity and specificity of each classification system. Results: Hearing loss results were highly variable (ranging from $29 \%$ to 61\%). Only 4 of 31 subjects with post-therapy hearing loss were identified by all the methods. A few subjects with hearing loss were classified as normal hearing in some of the criteria. A normal PTA was found in 18 of 31 subjects in the post-treatment evaluation. Conclusion: None of the criteria assesses the complaints of patients. The criteria described in this study were inadequate to identify hearing loss following chemotherapy, requiring additional information for physicians to better understand the hearing losses and their implications for the quality of life of patients.
\end{abstract}

${ }^{1}$ Master in science, Fundação Antonio Prudente. Speech therapist, Audiology Sector, Hospital do Câncer A C Camargo.

${ }^{2}$ Doctor in science of communication disorders, Universidade Federal de São Paulo. Speech therapist, Audiology Sector, Hospital do Câncer A C Camargo.

${ }^{3}$ Master in sciences, Fundação Antonio Prudente. Speech therapist, Audiology Sector, Hospital do Câncer A C Camargo.

${ }^{4}$ Livre-docente (habilitation) in oncology, FMUSP. Full surgeon, Head \& Neck Surgery and Otorhinolaryngology Department, Hospital de Barretos - Hospital do Câncer. Paper submitted to the BJORL-SGP (Publishing Management System - Brazilian Journal of Otorhinolaryngology) on May 2, 2008; and accepted on November 2, 2008. cod. 5829 


\section{INTRODUCTION}

Cisplatin (CDDP) is an antineoplastic drug used often in the treatment of various tumors. Side effects include: nausea, vomiting, myelosuppression nephrotoxicity, central and peripheral neuropathies, and ototoxicity (Oliveira ${ }^{1}$; Rybak et al. ${ }^{2}$ ). Ototoxicity may ensue when the drug is given at a cumulative dose over $360 \mathrm{mg} / \mathrm{m}^{2}$ (Brock et al..$^{3}$; Pedalini et al. ${ }^{4}$, Simon et al. ${ }^{5}$, Knoll et al. $\left.{ }^{6}\right)$. Cisplatin ototoxicity is the result of cochlear injury, initially in the vascular striae and the outer hair cells of the basal gyrus, which result in hearing loss at high frequencies (Rademaker et al. ${ }^{7}$; Rybak et $\mathrm{al}^{8}{ }^{8}$ ). Continued use of the drug may result in hearing loss at low frequencies (Pedalini et al. ${ }^{4}$, Zuur et al. ${ }^{9}$ ).

Hearing loss may cause significant loss in the quality of life of patients; thus, a concern with ototoxicity should be present throughout oncological therapy. Detecting and monitoring ototoxicity to initiate preventive measures is one of the methods for avoiding hearing loss.

Oncologists are increasingly concerned with drug toxicity in oncological therapy, and have created objective criteria to measure the specific toxicity for each organ during chemotherapy cycles.

Many criteria have been published in the literature, with the aim of identifying, describing and even quantifying hearing loss. In this paper we apply four instruments that will be described below (Davis and Silverman ${ }^{10}$; Brock et al. ${ }^{3}$; ASHA-American Speech-language-Hearing Association ${ }^{11} ; \mathrm{NCI}^{12}$ ).

In clinical practice, there criteria are difficult to apply, since they do not define clearly the degree of hearing loss or its impact - patient complaints are not taken into account - and do not include all types and grades of hearing alterations.

\section{OBJECTIVE}

The aim of this study was to assess and identify the characteristics of each classification method of hearing loss and to adapt them to oncological monitoring.

\section{METHOD}

A prospective study was proposed and approved by the Research Ethics Committee of the institution in which the investigation was to be conducted (acceptance number 549/03). All patients were consulted about their participation in the study, and signed a free informed consent form. Audiological assessments were carried out in 31 subjects seen at the Audiology unit; inclusion criteria were as follows: cisplatin chemotherapy only; absence of ontological complaints; no radiotherapy in the head and neck, and pre- and post-therapy audiological assessments.
There were 16 male and 15 female patients. Age ranged from 7 to 66 years; the mean age was 28 years.

All subjects in this study underwent full audiological testing before, during and after chemotherapy with CDDP; however, only conventional pure tone audiometry data were computed. A Madsen, Orbiter model version 922 audiometer was used for measuring air and bone conduction pure tone auditory thresholds (in dBHL) (Redondo et al. ${ }^{13}$; Yantis $\left.{ }^{14}\right)$.

Results were tabulated according to classifications proposed by various authors and entities. The CTCAE (Common Terminology Criteria for Adverse Events ${ }^{12}$ ) was proposed by the NCI (National Cancer Institute). This instrument aims to describe the adverse events due to chemotherapeutic drugs during oncological treatment; numerical values ( 1 to 4 ) were given to the reactions observed in each organ during each chemotherapy cycle (Annex 1).

Brock et al. ${ }^{3}$ attributed number values (0 to 4 ) to various types of hearing loss due to chemotherapy (Annex 2).

The ASHA ${ }^{11}$ considers ototoxicity as a $20 \mathrm{~dB}$ threshold elevation at a specific frequency, a $10 \mathrm{~dB}$ threshold elevation at two consecutive frequencies, or absent responses at three consecutive frequencies in post-therapy testing.

Davis and Silverman ${ }^{10}$ classify the degree of hearing loss according to the mean value of thresholds at 500, 1000 and $2000 \mathrm{~Hz}$; normal values - 0 to $20 \mathrm{~dB}$, mild hearing loss - 21 to $40 \mathrm{dBHL}$, moderate hearing loss - 41 to $70 \mathrm{dBHL}$, severe hearing loss - 71 to $90 \mathrm{dBHL}$, profound hearing loss - over $95 \mathrm{dBHL}$.

A comparison was done taking the $25 \mathrm{dBHL}$ threshold as the limit between normal hearing and hearing loss to assess the sensitivity and specificity of each criterion, with the aim of analyzing hearing loss according to frequency (PPF). Fisher's exact test was applied to study the significance of each method. The GraphPad Prism version 2.0 software was used. The significance level was $<0.05$.

\section{RESULTS}

Table 1 shows that, according to NCI12 criteria, 12 of 31 patients (38\%) presented hearing loss at the end of therapy. Of these, only one had grade I changes, 10 had grade II changes, and one had grade III changes. According to Brock et al.' ${ }^{3}$ criterion, 19 patients (61\%) presented hearing loss at the end of therapy. Of these, 5 had grade I changes, 5 had grade II changes, 5 had grade III changes, and 4 had grade IV changes. According to ASHA $^{11}$ criteria, 17 subjects (54\%) presented hearing loss at the end of therapy. Of these, 13 had a $10 \mathrm{~dB}$ loss in two or more frequencies, and 4 had a $15 \mathrm{~dB}$ loss or more in only one frequency. However, 39\% of patients had a loss over $15 \mathrm{~dB}$ in two or more consecutive frequencies in at least one ear. 
Annex 1. Table of the $\mathrm{NCl}$ proposed classification

Common Terminology Criteria for Adverse Events (CTCAE) (2003)

Cancer Therapy Evaluation Program, Common Terminology Criteria for Adverse Events

Version 3.0 DCTD, NCl, NIH, DHHS. March31, 2003 (http:// ctep.cancer.gov) Publishing date, 10 June 2003

\begin{tabular}{|c|c|c|c|c|c|c|}
\hline Hearing / Ear & & & & & & \\
\hline $\begin{array}{c}\text { Auditory Adverse } \\
\text { Event }\end{array}$ & Name & 1 & 2 & 3 & 4 & 5 \\
\hline
\end{tabular}

OBS: pediatric recommendations are similar to those of adults unless otherwise specified. For children and teenagers $(<$ or $=18$ years $)$ with no pre-treatment baseline audiogram, hearing is considered as below $5 \mathrm{~dB}$.

Hearing: patients
with no baseline
audiogram and Hearing: no moni-
not included in a $\quad$ toring program
monitoring pro-
gram

$\begin{array}{ccc}\text { Otitis, outer ear } & \text { Otitis external } \\ \text { with desquama- } & \text { Otitis external } \\ \text { (non- infectious) } & \text { tion, ear wax or } \\ \text { with erythema or } & \text { effusion, tympa- } \\ \text { dry desquamation } & \begin{array}{c}\text { nic perforation, } \\ \text { tympanoplas } \\ \text { ty }\end{array}\end{array}$

OBS: patients with or with no baseline audiogram, included or not in a monitoring program.

$\begin{array}{ccccc}\begin{array}{l}\text { Otitis, middle ear } \\ \text { (non- infectious) }\end{array} & \text { Otitis media } & \text { Otitis serous } & \begin{array}{c}\text { Otitis serous with } \\ \text { indication for me- } \\ \text { dical intervention }\end{array} & \begin{array}{c}\text { Otitis with effu- } \\ \text { sion, mastoiditis }\end{array} \\ \text { Tinnitus } & \text { Tinnitus } & - & \begin{array}{c}\text { Tinnitus not affec- } \\ \text { ting activities of } \\ \text { daily life }\end{array} & \begin{array}{c}\text { Tinnitus affecting } \\ \text { activities of daily }\end{array} \\ & & \text { life }\end{array}$

\begin{tabular}{|c|c|c|}
\hline $\begin{array}{l}\text { Hearing loss with } \\
\text { no need to use }\end{array}$ & $\begin{array}{l}\text { Hearing loss with } \\
\text { no deed to use }\end{array}$ & found bilateral \\
\hline $\begin{array}{l}\text { AASI (no effect on } \\
\text { activities of daily } \\
\text { life) }\end{array}$ & $\begin{array}{l}\text { AASI (affecting } \\
\text { activities of daily } \\
\text { life) }\end{array}$ & $\begin{array}{c}\text { hearing loss } \\
(>90 \mathrm{~dB})\end{array}$ \\
\hline
\end{tabular}

Otitis external

with mastoiditis, Necrosis of bone stenosis or oste- or soft tissues omyelitis
Death

Necrosis of canal,

of bone or soft Death

tissues

Disability

Loss of function

OBS: patients with or with no baseline audiogram, included or not in a monitoring program.

\begin{tabular}{|c|c|c|c|c|c|c|}
\hline $\begin{array}{c}\text { Hearing / Ear } \\
\text { Others }\end{array}$ & $\begin{array}{l}\text { Hearing / Ear } \\
\text { Others }\end{array}$ & mild & moderate & severe & $\begin{array}{l}\text { life risk / loss of } \\
\text { function }\end{array}$ & Death \\
\hline
\end{tabular}


Annex 2. Descriptive table of Brock et al.'s proposed classification (1991)

\begin{tabular}{lc}
\hline \multicolumn{1}{c}{ Hearing loss Bilateral } & Grade \\
\hline$<40 \mathrm{~dB}$ at all frequencies & 0 \\
$\geq 40 \mathrm{~dB}$ only at $8.000 \mathrm{~Hz}$ & 1 \\
$\geq 40 \mathrm{~dB}$ starting at $4.000 \mathrm{~Hz}$ & 2 \\
$\geq 40 \mathrm{~dB}$ starting at $2.000 \mathrm{~Hz}$ & 3 \\
$\geq 40 \mathrm{~dB}$ starting at $1.000 \mathrm{~Hz}$ & 4 \\
\hline
\end{tabular}

Davis and Silverman's ${ }^{10}$ criteria revealed that 9 subjects (29\%) had hearing loss at the end of therapy. The identification percentage of hearing loss varied considerably among criteria - from $29 \%$ to $61 \%$. We also found that $61 \%$ had auditory thresholds over $25 \mathrm{dBHL}$ in at least one frequency bilaterally.

Statistical analysis consisted of specificity and sensitivity calculations for each criterion; Fisher's test was applied to calculate the $\mathrm{p}$ value, as shown on the Table below.

Table 1. Distribution of hearing loss classifications in the study population according to the criteria applied.

\begin{tabular}{|c|c|c|c|c|c|}
\hline Patient & BROCK & ASHA (2002) & $\mathrm{NCl}$ & SILVERMAN & PPF \\
\hline 1 & 0 & 0 & 0 & Normal & Normal \\
\hline 2 & 0 & 0 & 0 & Normal & Normal \\
\hline 3 & 0 & 0 & 0 & Normal & Normal \\
\hline 4 & 0 & 0 & 0 & Normal & Normal \\
\hline 5 & 0 & 0 & 0 & Normal & Normal \\
\hline 6 & 0 & 0 & 0 & Normal & Normal \\
\hline 7 & 0 & 0 & 0 & Normal & Normal \\
\hline 8 & 0 & 1 & 0 & Normal & No \\
\hline 9 & 1 & 0 & 0 & Normal & No \\
\hline 10 & 0 & 1 & 0 & Normal & 8 \\
\hline 11 & 1 & 1 & 2 & Normal & 8 \\
\hline 12 & 0 & 0 & 0 & Normal & 6 \\
\hline 13 & 0 & 0 & 0 & Normal & 6 \\
\hline 14 & 0 & 1 & 0 & Normal & 250,500 \\
\hline 15 & 1 & 1 & 0 & Mild & 250,8 \\
\hline 16 & 2 & 0 & 0 & Normal & $4,6,8$ \\
\hline 17 & 3 & 0 & 2 & Mild & 6,8 \\
\hline 18 & 2 & 1 & 2 & Normal & $4,6,8$ \\
\hline 19 & 2 & 1 & 2 & Normal & $4,6,8$ \\
\hline 20 & 2 & 1 & 2 & Normal & $4,6,8$ \\
\hline 21 & 3 & 1 & 0 & Normal & $4,6,8$ \\
\hline 22 & 3 & 1 & 2 & Normal & $4,6,8$ \\
\hline 23 & 3 & 1 & 2 & Normal & $4,6,8$ \\
\hline 24 & 3 & 1 & 2 & Normal & $4,6,8$ \\
\hline 25 & 1 & 1 & 0 & Mild & 2.4.6.8 \\
\hline 26 & 4 & 1 & 2 & Mild & $2,3,4,6,8$ \\
\hline 27 & 2 & 0 & 0 & Mild & All \\
\hline 28 & 1 & 1 & 1 & Mild & All \\
\hline 29 & 4 & 1 & 2 & Mild & All \\
\hline 30 & 4 & 0 & 0 & Moderate & All \\
\hline 31 & 4 & 1 & 3 & Moderate & All \\
\hline
\end{tabular}


Table 2. Sensitivity and Specificity, with their respective confidence intervals $(\mathrm{Cl})$, for each criterion.

\begin{tabular}{|c|c|c|c|c|c|}
\hline \multirow[t]{2}{*}{ Criteria } & \multicolumn{5}{|c|}{ Hearing loss } \\
\hline & & & YES & NO & \\
\hline \multirow{2}{*}{ Brock } & \multirow{2}{*}{ Hearing loss } & YES & 18 & 1 & Specificity: $81.8 \%$ \\
\hline & & NO & 4 & 8 & Sensitivity: $88.9 \%$ \\
\hline \multirow{2}{*}{ ASHA (2002) } & \multirow{2}{*}{ Hearing loss } & YES & 16 & 1 & Specificity: $88.9 \%$ \\
\hline & & NO & 6 & 8 & Sensitivity: $72.7 \%$ \\
\hline \multirow{2}{*}{$\mathrm{NCl}$} & \multirow{2}{*}{ Hearing loss } & YES & 12 & 0 & Specificity: $100 \%$ \\
\hline & & NO & 10 & 9 & Sensitivity: $54.5 \%$ \\
\hline \multirow{2}{*}{ SILVERMAN } & \multirow{2}{*}{ Hearing loss } & YES & 9 & 0 & Specificity: $100 \%$ \\
\hline & & NO & 13 & 9 & Sensitivity: $40.9 \%$ \\
\hline
\end{tabular}

Table 2 shows Brock's $(1991)^{3}$ proposed criteria; it had the highest sensitivity. The NCI's ${ }^{12}$ and Davis and Silverman's ${ }^{10}$ criteria were the most specific.

\section{DISCUSSION}

The distribution of audiometric thresholds in the study sample showed that:

- Only 4 subjects with post-therapy hearing loss were identified by all criteria; 7 subjects had no hearing loss in any of the criteria applied in this study.

- Thirteen of 18 subjects with normal pure tone audiometry (according to Davis and Silverman ${ }^{10}$ ) after therapy had some degree of hearing loss according to the other methods applied in this study.

Brock et al.' $\mathrm{s}^{3}$ criteria demonstrated the highest number of significant hearing losses; the ASHA ${ }^{11}$ criteria only revealed whether there was hearing loss or not, but provided no quantification.

Auditory losses due to cisplatin ototoxicity are generally symmetrical, bilateral, initially affecting high frequencies, followed by middle and low frequencies (Testa et al. ${ }^{15}$; Rademaker et al..$^{7}$ ).

Changes were not always detected at the beginning by the criteria described above. A major point about these criteria is that they do not take the complaints of patients into account, which would be extremely important. Additionally, the impact on a patient's life may not be proportional to the degree of hearing loss, since this impact depends on factors such as social and professional activities and personal aspects. The growing concern on the part of oncologists should lead to careful prevention of hearing loss, comprising periodic testing and close monitoring of hearing losses, not waiting for patients to complain before becoming concerned with hearing; this means preventing the onset of hearing loss and not only rehabilitation when hearing cannot be recovered any longer.

A relevant point was that $\mathrm{NCI}^{12}$ criteria were not sufficiently specific for monitoring auditory function; it does not define clearly which frequencies should be investigated.

Audiologically, there are monitoring proposals using conventional frequencies (Testa et al. ${ }^{15}$, Kushner et al. ${ }^{16}$, Marshall et al. ${ }^{17}$, Toral-Martinnon et al. ${ }^{18}$ ), monitoring proposals using transient otoacoustic emissions (Liberman ${ }^{19}$ ) or distortion products (Biro et al. ${ }^{20}$; Hyppolito et al. ${ }^{21}$ ), and monitoring proposals using high frequencies (over $8000 \mathrm{~Hz}$ ) (Garcia ${ }^{22}$ ), which may be first affects by ototoxic drugs. In this case, patients with hearing loss normally do not complain and not always perceive loss of hearing (Liberman ${ }^{23}$ ). Dhooge et al., ${ }^{24}$ however, found symptomatic ototoxicity in $20 \%$ of cases - auditory complaints in 16 children treated with cisplatin and/or carboplatin. Monitoring with conventional frequencies (500 to 8000 $\mathrm{Hz}$ ) shows that hearing loss leads to difficulties in different situations; patients may complain only of tinnitus or difficulties to understand speech in noisy environments, or may present hearing loss at speech frequencies, no longer being able to follow a conversation. Still in the criterion for patients with auditory changes in pre-therapy testing, these subjects may be classified as not having post-therapy auditory changes; but therapy will have caused elevated audiometric thresholds, which are not taken into account in the final criterion.

A further discrepancy is the grade II in this criterion. This grade includes patients that had a 25 to $90 \mathrm{~dB}$ elevation of the auditory threshold. A $25 \mathrm{~dB}$ threshold elevation may go unnoticed or may cause minimal difficulty; it may even be classified as mild hearing loss (Davis and Silver$\left.\operatorname{man}^{10}\right)$. On the other hand, a $90 \mathrm{~dB}$ elevation suggests that subjects will probably not follow a conversation without using hearing aids, since voice during a conversation is issued at around $60 \mathrm{dBHL}$. Furthermore, hearing loss here is classified as severe, which brings significant restrictions on social life. Classifying these two extremes of threshold elevations in the same grade does not take into account the significant differences, complaints and limitations. 
The $40 \mathrm{~dB}$ reference in Brock et al.' ${ }^{10}$ proposed criteria is debatable. A $40 \mathrm{~dB}$ loss characterizes mild hearing loss, with serious implications for the perception of Portuguese consonants (Russo and Behlau ${ }^{25}$ ), especially in children, for which this classification was proposed. This author does not take into account changes above $40 \mathrm{~dB}$ that may occur at single frequencies, as well as not considering small auditory alterations that may occur before the auditory threshold reaches $40 \mathrm{~dB}$. Intensity is an important factor in hearing loss; it is also important in rehabilitation with hearing aids, and may be a limiting factor in choosing and using an appropriate aid.

The ASHA $^{11}$ criteria do not account for affected frequencies; from an audiological perspective this has implications for the follow-up of oncological therapy. A $10 \mathrm{~dB}$ threshold increase at 6000 and $8000 \mathrm{~Hz}$ may not result in minimal hearing loss, depending on age, while a $20 \mathrm{~dB}$ decrease at 1000 and $2000 \mathrm{~Hz}$ in a patient with a 30 $\mathrm{dB}$ pre-treatment threshold causes moderate hearing loss and may result in significant communication difficulties. Thus, the affected frequency should be taken into account.

Davis and Silverman ${ }^{10}$ proposed criteria is not indicated for oncological patients, since it classifies hearing loss only at 500, 1000 and $2000 \mathrm{~Hz}$ thresholds, which are not those commonly involved in ototoxicity.,26-27 This is a problem, because when ototoxic drug induced hearing loss affects these frequencies, loss is already significant and patients present major complaints; it is thus inadequate for monitoring patients at risk of hearing loss - when this criterion detects loss, it is already rather advanced.

The same subject with hearing loss was not always classified by all of the criteria above; thus, the sensitivity and/or specificity of each criterion needs to be known, as small changes in hearing are not always detected by these instruments. Important hearing losses are easily detected by any of these tools; however, a classification instrument should detect small changes so that oncologists and speech therapists may carefully monitor the hearing function of these patients, to avoid major loss of function.

The classification of hearing loss in audiological evaluations during oncological therapy aims firstly to identify ototoxic effects, especially at high frequencies. This makes it possible for physicians to be alert and change therapy protocol measures. Secondly, the classification should indicate at which point patients will suffer the social, educational and professional implications of hearing loss. Impact differs in adults and children, both in terms of the degree of hearing loss and the affected frequencies. A classification should be able to show the progression of hearing loss.

Knight et al. ${ }^{28}$ monitored ototoxicity in 67 children with osteosarcoma, neuroblastoma and medulloblastoma, all of which were treated with cisplatin. These authors compared the Brock et al., ${ }^{3}$ ASHA, ${ }^{11}$ and $\mathrm{NCI}^{12}$ criteria, and also found it difficult to adequately describe hearing losses. These authors believe that those criteria underestimate hearing loss resulting from oncological therapy; the result of this is that language development, learning and social/ emotional function may be compromised in these children. These authors also found that hearing loss may lead to low self-esteem, behavioral disorders, loss of energy and stress, compared to normal hearing children; these factors are not included in any of these classification systems.

Liberman $^{29}$ studied patients with cancer treated during childhood with cisplatin, and found a higher occurrence of auditory complaints when hearing loss affected the $4000 \mathrm{~Hz}$ frequency.

Marini et al. ${ }^{30}$ analyzed the predictive power, sensitivity and specificity of auditory complaints in 795 patients and found that the sensitivity was high (80.9\%) and the specificity was $60.4 \%$. Audiometric test results should also be available; although more subjective, these results are less costly than new technologies.

Teles et al. ${ }^{31}$ compared data such as frequency, proportion, agreement and consistency of responses in workers exposed to occupational noise; significant changes were noted in the audibility threshold (MSL). These authors applied three Brazilian criteria and one international criterion to analyze threshold changes and found that these criteria in themselves were inadequate, given their subjective nature; prevention would be necessary not only in subjects presenting MSL but in all subjects in an auditory preservation program.

Gupta et al. ${ }^{32}$ found a small incidence of hearing loss in children undergoing cisplatin chemotherapy by continuous infusion; these authors used Brock's criterion and concluded that continuous drug administration is associated with a lower incidence of ototoxicity. However, we believe that this criterion underestimates important losses in this population because it takes into account only losses over $40 \mathrm{~dB}$.

According to the literature we cited, changes in hearing were not always detected at the beginning in oncological patients by the criteria described in this study. The main criticism of these criteria is that they do not include patient complaints, essential for understanding the impact of hearing loss on patient's lives, which are not always proportional do the degree of loss, but depend on factors such as personal, social and professional activities. The growing concern of oncologists should lead to preventive care to avoid hearing loss; this includes periodic testing and close monitoring of auditory changes before patients complain to avoid hearing loss rather than just rehabilitation when reversion is no longer possible.

Each classification tool should be assessed according to its purpose. In the case of hearing loss associated with oncological therapy, we believe it is relevant not only to identify, classify and quantify auditory losses, but 
also to investigate eventual complains and the impact that hearing loss may cause on the quality of life of patients. It is impossible to define the degree of hearing loss that results in complaints and difficulties for patients using only the criteria mentioned above for classifying auditory losses. Thus, identifying and validating the complaints of patients is just as important as audiological evaluations and classification of losses according to charts.

It is extremely important to note that the criterion used for classifying hearing losses in oncological patients should be able to identify the beginning of loss, thus avoiding unnecessary adverse effects and preventing auditory losses due to oncological therapy.

\section{CONCLUSION}

We found that Davis and Silverman's ${ }^{10}$ criteria showed hearing loss in 29\% of subjects at the end of treatment; the $\mathrm{NCI}^{12}$ criteria showed hearing loss in 38\% of patients; the $\mathrm{ASHA}^{11}$ criteria showed hearing loss in 54\%; and Brock et al.'s ${ }^{3}$ criteria showed hearing loss in $61 \%$ of patients at the end of oncological therapy. Thus, Brock's (1991) ${ }^{3}$ proposed criteria was the most sensitive, and the NCI's ${ }^{12}$ and Davis and Silverman's ${ }^{10}$ criteria were the most specific.

However, all of these criteria underestimated the description of identified auditory alterations; additional information was required to help physicians to understand the true implications of hearing loss in each case.

A common code is needed between audiologists and oncologists to increase our understanding and improve the therapy of these patients; not only should the grade and type of hearing loss be described, but also the impact on the lives of patients.

\section{REFERENCES}

1. Oliveira JAA. Ototoxicidade. In: Costa SS, Cruz OLM, Oliveira JAA. Otorrinolaringologia. Porto Alegre: Artes Medicas Sul; 1994. p.215-21.

2. LP, Whitworth CA. Ototoxicity: therapeutic opportunities. Drug Discov Today. 2005; 10:1313-21.

3. Brock PR, Bellman SC, Yeomans EC, Pinkerton R, Pritchard J. Cisplatin ototoxicity in children: a practical grading system. Med Pediatr Oncol. 1991;19:295-300.

4. Pedalini MEB, Toniosso S, Goffi MVS. O papel do audiologista no tratamento do pacientes com câncer. In: Barros APB, editor. Fonoaudiologia em cancerologia. São Paulo: Fundação Oncocentro de São Paulo; 2000. p.105-9.

5. Simon T, Hero B, Dupuis W, Selle B, Berthold F. The incidence of hearing impairment after successful treatment of neuroblastoma. Klin Padiatr. 2002;214:149-52.

6. Knoll C, Smith RJ, Shores C, Blatt J. Hearing genes and cisplatin deafness: a pilot study. Laryngoscope. 2006;116:72-4.

7. Rademaker-Lakhai JM, Crul M, Zuur L, Baas P, Beijnen JH, Simis YJ, et al. Relationship between cisplatin administration and the development of ototoxicity. J Clin Oncol. 2006;20:918-24.

8. Rybak LP, Whitworth CA, Mukherjea D, Ramkumar V. Mechanisms of cisplatin-induced ototoxicity and prevention. Hear Res. 2006;226:15767.
9. Zurr CL, Simis YJ, Landsdaal PE, Rasch CR, Tange RA, Balm AJ, Dreschler WA. Audiometric Patterns in Ototoxicity of Intra-Arterial Cisplatin Chemoradiation in Patients with Locally Advanced Head and Neck Cancer. Audiol Neurootol. 2006;11:318-30.

10. Davis H, Silverman SR. Hearing and Deafness, 4th ed. New York, Holt, Rinehart \& Winston, 1978.

11. American Speech-Language-Hearing Association (ASHA). Guidelines for the Audiologic Management of Individuals Receiving Cochleotoxic Drug Therapy. ASHA. 2002;2:81-92.

12. NCI. National Cancer Institute. Common Terminology Criteria for Adverse Events (CTCAE) version 3.0 (2003). Disponível em: < URL:http://ctep.cancer.gov/reporting/ctc.html. Acessado em 21 de maio de 2006.

13. Redondo MC, Lopes Filho OC. Testes básicos da avaliação auditiva. In: Lopes Filho OC. Tratado de fonoaudiologia. São Paulo: Roca; 1997. p.81-108.

14. Yantis PA. Pure air conditioning thresholds listing. In: Katz J, editor Handbook of clinical audiology. 4th ed. Baltimore: Willian \& Wilkins; 1994. p.97-108.

15. Testa JR, Liberman PHP, Goffi-Gomez MV S. Complicações otorrinolaringológicas do tratamento oncológico. In: Kowalski LP, Anelli A, Salvajoli JV, Lopes LF. Manual de Condutas diagnósticas e terapêuticas em oncologia. São Paulo: Ambito Editorial; 2002. p.395-7.

16. Kushner BH, Budnick A, Kramer K, Modak S, Cheung NK. Ototoxicity from high-dose use of platinum compounds in patients with neuroblastoma. Cancer. 2006; 107: 417-22.

17. Marshall NE, Ballman KV, Michalak JC, Schomberg PJ, Burton GV, Sandler HM, et al. Ototoxicity of cisplatin plus standard radiation therapy vs. accelerated radiation therapy in glioblastoma patients. J Neurooncol. 2006;77:315-20.

18. Toral-Martinnon R, Collado-Corona MA, Mora-Magana I, Leal-Leal C, Gutierrez-Castrellon P, Gonzalez-De Leo S. Evaluation of cisplatin ototoxicity by the audiometric curve in retinoblastoma. Cir Cir. 2006; 74:79-82.

19. Liberman PHP. Monitorizaçäo auditiva em crianças portadoras de retinoblastoma: relato de dois casos. Acta Oncol Bras. 2002;22:250-4.

20. Biro K, Noszek L, Prekopp P, Nagyivanyi K, Geczi L, Gaudi I, et al. Characteristics and risk factors of cisplatin-induced ototoxicity in testicular cancer patients detected by distortion product otoacoustic emission. Oncology. 2006;70:177-84.

21. Hyppolito MA, de Oliveira JA, Rossato M. Cisplatin ototoxicity and otoprotection with sodium salicylate. Eur Arch Otorhinolaryngol. 2006; 263:798-803.

22. Garcia AP, Irio MCM, Petrilli A S. Monitoramento da audição de pacientes expostos à cisplatina. Rev Bras Otorrinolaringol. 2003 69:215-21.

23. Liberman PH, Schultz C, Gomez MV, Carvalho AL, Pellizzon AC, Testa JR, et al. Auditory effects after organ preservation protocol for laryngeal/ hypofaryngeal carcinomas. Arch Otolaryngol Head Neck Surg. 2004; 130:1265-8.

24. Dhooge I, Dhooge C, Geukens S, De Clerck B, De Vel E, Vinck BM Distortion product otoacoustic emissions: an objective technique for the screening of hearing loss in children treated with platin derivatives. Int J Audiol. 2006; 45:337-43.

25. Russo I, Behlau M. Percepçäo da fala: análise acústica do português brasileiro. Säo Paulo: Lovise. 1993. p.25-50.

26. Li Y, Womer RB, Silber JH. Predicting cisplatin ototoxicity in children: the influence of age and the cumulative dose.Eur $\mathrm{J}$ Cancer. 2004; $40: 2445-51$.

27. Langer T, Stohr W, Bielack S, Palussen M, Treuner J, Beck JD. Late effects surveillance system for sarcoma patients. Pediatr Blood Cancer. 2004;42:373-9.

28. Knight KRG, Kraemer DF, Neuwelt EA. Ototoxicity in children receiving platinum chemotheraphy: underestimating a commonly occuring toxicity that may influence academic and social development. J Clin Oncol. 2005;23:8588-96. 
29. Liberman PHP. Avaliação Auditiva em pacientes tratados de câncer na infância. [Dissertação]. Fundação Antonio Prudente, São Paulo; 2005.

30. Marini ALS, Halpern R, Aetrs D. Sensibilidade, especificidade e valor preditivo da queixa auditiva. Rev Saude Publica 2005;39:982-4.
31. Teles RM, Sena APRC, Medeiros MPH. Estudo comparativo entre critérios de análise da mudança significativa do limiar (MSL) Fono Atual. 2002;5:53-9.

32. Gupta AA, Capra M, Papaioannou V, Hall G, Maze R, Dix D, et al Low incidence of ototoxicity with continuous infusion of cisplatin in the treatment of pediatric germ cell tumors. J Pediatr Hematol Oncol. 2006;28:91-4. 